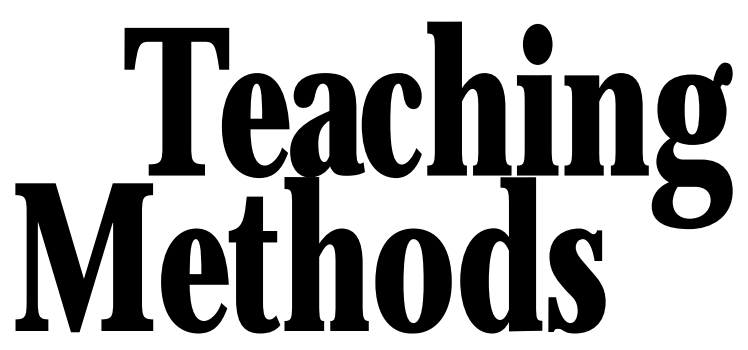

\section{Factors Affecting Recruitment of Horticulture Students at Major Universities}

\author{
Jennifer C ampbell Bradley, ${ }^{1}$ \\ Tammy Kohlleppel, ${ }^{2}$ \\ Tina M. Waliczek, ${ }^{3}$ and \\ Jayne M . Zajicek ${ }^{4}$
}

\begin{abstract}
AdDitional INDEX WORds. college recruiting, horticulture majors, horticulture enrollment, recruitment factors, choice of major
\end{abstract}

Summary. R esearchers at the $U$ niversity of Florida and Texas $A \& M$ $U$ niversity developed a survey to gain insight into demographic and educational influences on undergraduate students who major in horticulture. Five universities participated in the study of undergraduate horticulture programs. These included the $U$ niversity of Florida, Texas A\& M U niversity, O klahoma State U niversity, U niversity

Florida Agricultural Experiment Station, J ournal Series $\mathrm{No}$. R-06922. The cost of publishing this paper was defrayed in part by the payment of page charges. U nder postal regulations, this paper therefore must be hereby marked advertisement solely to indicate this fact.

${ }^{1}$ Assistant professor, Department of Environmental $\mathrm{H}$ orticulture, U niversity of Florida, Gainesville, FL 32611.

${ }^{2} \mathrm{G}$ raduatestudent, D epartment of Environmental H orticulture, U niversity of Florida, Gainesville, FL 32611.

${ }^{3}$ Assistant professor, D epartment of Agriculture, Illinois State U niversity, N ormal, IL 61790.

${ }^{4}$ Professor and associate department head, D epartment of $\mathrm{H}$ orticultural Sciences, Texas A\& M U niversity, College Station, TX 77843. of Tennessee, and Kansas State $U$ niversity. A bout 600 surveys were sent to schools during the 1997 fall semester. The questionnaires were completed by horticulture majors and nonmajors taking classes in horticulture departments. The survey consisted of two main sections. The first section, which was completed by all students, explored student demographic information, high school history, university history, and horticulture background. O nly horticulture majors completed the second section, which examined factors influencing choice of horticulture as a major. Statistically significant differences were found between horticulture majors and nonmajors when comparing the two groups on the variables of transfer status, gardening experiences, and the importance of gardening. There was a significantly higher percentage of transfer students among horticulture majors. The decision to major in horticulture occurred somewhat early in academic programs, with the largest representations in high school or early in college. 0 verall, majors had more gardening experience than nonmajors and considered the hobby of gardening as a strong influence in choosing their major. This information should be considered in recruitment efforts since students reported that this interest fostered in them a desire to pursue horticulture as a major. School garden programs at the primary level and horticulture classes at the high school level could possibly influence more students to choose horticulture as a major at the college level. Currently, trends in recruiting efforts in academic programs at the university level are intense and competitive, as students are given more and more career option information. Consequently, data from this study may be useful for horticulture departments developing targeted recruiting programs.
$\mathrm{T}$ he horticulture industry, which includes the production, design, and maintenance of plantsfor aesthetic and utilitarian purposes, is the direct result of people's affection and need for plants. Job opportunities and the consequential demand for horticulture professionals are the factors that have elevated horticulture into a leading academic area in collegiate agriculture programs throughout the $U$ nited States.

At the postsecondary education level, horticulture programs are offered throughout the U nited States at 114 collegesand universitiesinvolving about 5,500 students (American Society for H orticultural Science, unpublished data). Theseinstitutionsare responsible for preparing students for varied careers in horticulture including fruit and vegetable production, ornamental plant production, and theturfgrass, landscape, and floriculture industries.

$\mathrm{H}$ orticultureisdeep-seated within the American culture with about onequarter of Americans practicing some form of gardening (Roper Reports, 1997). U nquestionably, society has a strong affection for nature and plants, contributing to a strong horticulture industry. The commercial worth of horticultural plantsiswell known. The U nited States' green industry (floriculture and ornamental horticulture) is the fastest growing agricultural sector in grower cash receipts, with an average annual growth rate of $9 \%$ (Johnson and Johnson, 1993). The ornamental horticulture and floral industries represent nearly $10 \%$ of all crop agriculture- ranking ahead of wheat (Triticum aestivum L.), cotton (G ossypium hirsutum L.), and tobacco ( $N$ icotiana tabacum L.) (Society of American Florists, 1996). In Florida alone, ornamental plantsconstitutethe leading agricultural commodity with a value of nearly $\$ 42.2$ billion (H odges, 1989). Consequently, thehorticulture industry is in an enviable position of marketing a product that is of significant economic importance.

N o known statistical datahasbeen compiled and analyzed to document possible variables influencing horticulturestudent enrollment and itsfluctuations. As many departments are turning to recruiting efforts to increase student enrollment, no current research exists documenting factorsand demographic variables that may influence the student making horticulture a 
choice for academic pursuits.

Research has shown that environmental factors have influenced people's awareness of and subsequent interest in career options (C ooper-M arcus, 1974; Tanner, 1980). Tanner (1980) and Cooper-M arcus (1974) found that individuals who had childhood interests in outdoor activities such as fishing, hunting, and bird watching usually became involved in nature conservation or landscape architecture as adults. U nfortunately, in the horticultural sciences, research has not been completed to document if specific variables such as gardening as a child or participation in 4-H programs affect the choice of horticulture as a major and ultimately as a career. Consequently, a research initiative is needed to clearly document these factorsand theinfluence of demographic variables on students' choice of collegiate major of study.

The primary goal of this research wasto determineinformation that may help universities understand their student's motivations for academic pursuits to ultimately enhance recruitment into horticulture. The objectives of this study were to determine 1 ) the demographic background studentsthat decide to major in horticulture have in comparison to nonhorticulture majors, 2) the educational status of students entering horticulture programs compared to nonhorticulture majors, 3 ) if past horticultural experiences play a role in choice of majors for college students, and 4) when most students choose horticulture as a major and the primary outside influences that help them make this decision.

\section{Materials and methods}

In 1997, five departments of horticulture, theU niversity ofF lorida, Texas A\& M U niversity, O klahomaStateU niversity, U niversity of Tennessee, and Kansas State U niversity participated in an evaluation of their student popula- tion. A survey was developed and pilot tested at the U niversity of Florida and at T exasA\& M U niversity in spring, 1997. The survey was refined and distributed by the five departments during the fall semester, 1997. Six hundred surveys, along with instructions and a postagepaid return envelope were mailed to participating departments and administered to majors and nonmajors in horticulture classes. All studentswere degree seeking, with nonmajors representing a variety of agricultural and nonagricultural majors. Of these questionnaires, 315 individual surveys were returned, for a return rate of $53 \%$ representing 156 majors and 159 nonmajors from the five participating universities.

The survey consisted of four sections: student information, university history, horticulture background, and factorsinfluencing horticultureaschoice of major. Student information included general demographic data such as gender and ethnicity. Theuniversity history

T able 1. R elationships of demographic variables and college student horticulture majors and nonmajors.

\begin{tabular}{|c|c|c|c|c|c|}
\hline \multirow[b]{2}{*}{ Variable } & \multicolumn{2}{|c|}{ Major } & \multirow[b]{2}{*}{$\begin{array}{l}\text { H orticulture } \\
\text { (no.) }\end{array}$} & \multirow[b]{2}{*}{$\begin{array}{c}\text { Nonhorticulture } \\
(\%)\end{array}$} & \multirow[b]{2}{*}{$\begin{array}{l}\text { Statistical } \\
\text { difference }\end{array}$} \\
\hline & $\begin{array}{c}\text { H orticulture } \\
\text { (no.) }\end{array}$ & $\begin{array}{c}\text { Nonhorticulture } \\
(\%)\end{array}$ & & & \\
\hline Gender & & & & & $0.194^{z}$ \\
\hline M ale & 85 & 54.5 & 75 & 47.2 & \\
\hline Female & 71 & 45.5 & 84 & 52.8 & \\
\hline Ethnicity & & & & & $0.116^{y}$ \\
\hline Caucasian & 148 & 94.9 & 145 & 91.2 & \\
\hline A frican American & 0 & 0.0 & 1 & 0.6 & \\
\hline $\mathrm{H}$ ispanic & 4 & 2.6 & 3 & 1.9 & \\
\hline Asian & 0 & 0.0 & 5 & 3.1 & \\
\hline $\mathrm{N}$ ative American & 4 & 2.6 & 2 & 1.3 & \\
\hline O ther & 0 & 0.0 & 2 & 1.3 & \\
\hline Age & & & & & $0.526^{y}$ \\
\hline $18-20$ & 66 & 42.3 & 68 & 42.8 & \\
\hline $21-23$ & 64 & 41.0 & 74 & 46.5 & \\
\hline $24-26$ & 9 & 5.8 & 8 & 5.0 & \\
\hline $27-30$ & 6 & 3.8 & 6 & 3.8 & \\
\hline $31-35$ & 5 & 3.2 & 1 & 0.6 & \\
\hline $36-40$ & 2 & 1.3 & 0 & 0.0 & \\
\hline $41-45$ & 2 & 1.3 & 1 & 0.6 & \\
\hline$\geq 46$ & 2 & 1.3 & 1 & 0.6 & \\
\hline M arital status & & & & & $0.541^{z}$ \\
\hline M arried & 18 & 11.5 & 15 & 9.4 & \\
\hline Single & 136 & 87.2 & 142 & 89.3 & \\
\hline $\mathrm{H}$ igh school grade & & & & & $0.166^{y}$ \\
\hline $95-100$ & 31 & 20.1 & 51 & 32.1 & \\
\hline $90-94$ & 38 & 24.7 & 39 & 24.5 & \\
\hline $85-89$ & 44 & 28.6 & 40 & 25.2 & \\
\hline $80-84$ & 28 & 18.2 & 21 & 13.2 & \\
\hline $75-79$ & 11 & 7.1 & 6 & 3.8 & \\
\hline$\leq 74$ & 2 & 1.3 & 1 & 0.6 & \\
\hline
\end{tabular}

${ }^{\mathrm{z}} \mathrm{R}_{\text {phi }}$ correlation coefficient.

${ }^{y} \mathrm{C}$ ramer's $\mathrm{V}$ correlation coefficient. 
section explored student status, including transfer versusfreshmen entrance as well as student residency status. The horticulture background section surveyed students about gardening experience and the value of gardening to the participating individual. Thefourth section contained questions evaluating when students made the decision to major in horticulture as well as the external influenceson the decision making process.

All data were analyzed using the Statistical Package for the Social Sciences for Windows release 7.0 (SPSS, 1997). Data were entered into SPSS spreadsheets. D uring statistical analysis, any missing answers to survey questions were coded as missing values. D escriptive statistics such as frequencies and percentages were cal culated for all variablesofinterest. Additionally, chi-square analyses were completed for areas of specific interest.

\section{Results and discussion}

Objective 1: Determine what deMOGRAPHIC BACKGROUND STUDENTS THAT DECIDE TO MAJ OR IN HORTICULTURE HAVE IN COMPARISON TO NONHORTICULTURE MAJ ORS. D emographic information among university studentshas been changing for at least the past four decades(Astin, 1998). One of the most obvious changes during this time has been an increase in the number of women pursuing advanced degrees today compared to the $1960 \mathrm{~s}$ (67\%compared to $40.3 \%$ ). Women have al so been choosing different career paths from thosechosen in the 1960s, including those in medicine, law and business compared to teaching and theartsin the past (Astin, 1998). In the past 20 years, thenumber of minority (Asian, $\mathrm{H}$ ispanics, African A mericansand $\mathrm{N}$ ativeA meri- cans) undergraduate students has increased substantially (Pascarellas and Terenzini, 1998). Because of these changing demographic trends, ademographicinformation section wasincluded in the survey to investigate the population of students included in this study.

Results indicated that for nonmajors, $47.2 \%$ were male while $52.8 \%$ were female (Table 1 ). For horticulture majors, $54.5 \%$ of the respondents were male, while $45.5 \%$ were female, indicating no statistical significant differences between the two groups. This information corresponds with resultsfrom the Cooperative I nstitutional Research Program (CIRP) which found that the percentages of women entering college since 1966 have gradually switched from a minority of $45.7 \%$ to a majority of $55.3 \%$ (Astin, 1998). This comparison information from the CIRP showsthat thehorticulture departments in this study are, perhaps, underrepresented in terms of percentages of women within the departments. The 30-year CIRP trend reported that gender differences for many career interest areas had been eliminated and that there has been a convergence of maleand female interests(Astin, 1998).

In addition to gender issues, another area that has received a great amount of attention within higher education institutionsthroughout the country has been the issue of race and diversity. Colleges and universitiesare taking steps to ensure that ethnic diversity exists within their educational systems (H urtado et al., 1998; J ackson, 1998). Research supports that diversity within an institution improves the climate by increasing opportunities for interaction across ethnic barriers and by providing more social and cultural experiencesfor students (H urtado et al., 1998; Kanter, 1977).

Results from this study indicated that for nonhorticulture majors, $91.2 \%$ of the respondents were $C$ aucasian and of the horticulture students involved in thestudy, 94.9\%were Caucasian (T able 1). This difference between majors and nonmajors was not statistically significantly different. These findings were somewhat discouraging, indicating a definite need for recruitment efforts towards diversity within universities as well as individual horticulture departments. Since 1984, American colleges and universities have witnessed a $61 \%$ increase in the total number of Asian, $\mathrm{H}$ ispanic, African American and $\mathrm{N}$ ative American undergraduates compared to $5.1 \%$ of $C$ aucasian students ( $\mathrm{H}$ urtado et al., 1998). H owever, the results of this study indicate that thegrowing number of minority students overall in colleges are not represented in horticulture programs. This could create problems in recruiting students since research has shown that minorities in majority $\mathrm{Cau}$ casian environments experience minority status stress (Prillerman et al., 1989; Smedley et al., 1993). Students are less likely to feel comfortable and remain in environments in which they are minorities. $\mathrm{H}$ owever, research indicated that students attending universities where they felt they were valued by faculty and administrators were less likely to report racial-related problems (H urtado et al., 1998). Clearly, horticulturedepartments should take steps toward improving departmental climates for diversity by increasing the representation of minority students and ensuring students feel valued in the classroom.

Regarding age and marital status, no statistical differences were found

Table 2. R elationships of educational status and college student horticulture majors and nonmajors.

\begin{tabular}{lccccc}
\hline & \multicolumn{2}{c}{ Major } & & \\
\cline { 2 - 5 } Variable & $\begin{array}{c}\text { H orticulture } \\
\text { (no.) }\end{array}$ & $\begin{array}{c}\text { Nonhorticulture } \\
(\%)\end{array}$ & $\begin{array}{c}\text { H orticulture } \\
\text { (no.) }\end{array}$ & $\begin{array}{c}\text { Nonhorticulture } \\
\text { (\%) }\end{array}$ & $\begin{array}{c}\text { Statistical } \\
\text { difference }\end{array}$ \\
\hline $\begin{array}{l}\text { Transfer status } \\
\text { No }\end{array}$ & 85 & 54.5 & 119 & 74.8 & $<0.0001^{*}$ \\
$\quad$ Yes & 71 & 45.5 & 40 & 25.2 & \\
Residency status & & & & & $0.160^{z}$ \\
In state & 131 & 85.1 & 145 & 91.2 & \\
$\quad$ Out of state & 20 & 12.9 & 12 & 7.5 & \\
International & 3 & 1.9 & 1 & 0.06 & \\
\hline
\end{tabular}

${ }^{2} \mathrm{R}_{\text {phi }}$ correlation coefficient.

${ }^{y}$ Cramer's V correlation coefficient.

*Statistically significant at $\mathrm{P}=0.05$. 
T able 3. Frequencies, percentages and statistical significance results for chi-square analyses of the gardening experience for horticulture majors and nonmajors participating in the study.

\begin{tabular}{lccccc}
\hline & \multicolumn{2}{c}{ Major } & & \\
\cline { 2 - 4 } Variable & $\begin{array}{c}\text { H orticulture } \\
\text { (no.) }\end{array}$ & $\begin{array}{c}\text { N onhorticulture } \\
\text { (\%) }\end{array}$ & $\begin{array}{c}\text { H orticulture } \\
\text { (no.) }\end{array}$ & $\begin{array}{c}\text { Nonhorticulture } \\
\text { (\%) }\end{array}$ & $\begin{array}{c}\text { Chi- } \\
\text { square }\end{array}$ \\
\hline H ave you ever gardened? & & & & & $<0.0001$ \\
N o & 19 & 12.2 & 67 & 42.7 & \\
Yes, 1-3 years & 58 & 37.2 & 48 & 30.6 \\
Yes, 4-8 years & 37 & 23.7 & 20 & 12.7 \\
Yes, $\geq 8$ years & 42 & 26.9 & 22 & 14 \\
\hline
\end{tabular}

T able 4. Frequencies, percentages and statistical significance results for chi-square analyses of the importance of gardening to horticulture majors and nonmajors participating in the study.

\begin{tabular}{lccccc}
\hline & \multicolumn{2}{c}{ Major } & & \\
\cline { 2 - 5 } Variable & $\begin{array}{c}\text { H orticulture } \\
\text { (no.) }\end{array}$ & $\begin{array}{c}\text { N onhorticulture } \\
\text { (\%) }\end{array}$ & $\begin{array}{c}\text { H orticulture } \\
\text { (no.) }\end{array}$ & $\begin{array}{c}\text { Nonhorticulture } \\
\text { (\%) }\end{array}$ & $\begin{array}{c}\text { Chi- } \\
\text { square }\end{array}$ \\
\hline H ow important is gardening to you? & & & & & $<0.0001$ \\
$\quad$ Very important & 54 & 35.3 & 13 & 9.4 & \\
Important & 58 & 37.9 & 48 & 34.5 \\
$\quad$ Undecided & 27 & 17.6 & 49 & 35.3 \\
$\quad$ Unimportant & 5 & 3.3 & 24 & 18 \\
$\quad$ Very unimportant & 9 & 5.9 & 4 & 2.9 \\
\hline
\end{tabular}

between horticulture majors and nonmajors (Table 1). For age, thelargest groups represented for both groups wasin the 18 to 20 and 21 to 23 year old age range, with $83.3 \%$ of horticulture majors and $89.3 \%$ of nonmajors responding in these categories. M arital status for the groups were also similar. For nonmajors, $89.3 \%$ of the students were single, while $87.2 \%$ of the majors were single.

The high school grade average for majors showed the strongest percentages in the 85 to 89 grade range, with $28.6 \%$ of the students making high Bs (Table 1). For nonmajors, the percentages of high grades were higher, although not statistically. Themajority of nonmajorsindicated grades in the 95 to 100 grade range (32.1\%). There has been a nationwide trend of increasing grade point averages since 1990. N early $32 \%$ of college freshmen have A- or better grade averages (Astin, 1998). The percentages of college freshmen with $\mathrm{C}+$ or lower grade point averages have decreased. These higher grades have been contributed to an increase in student competitivenessto get accepted and remain in college programs (Astin, 1998).

Obj ective 2: Determine the eduCATIONAL STATUS OF STUDENTS ENTERING HORTICULTURE PROGRAMS COMPARED TO NONHORTICULTURE MAJ ORS. For recruiting purposes, this survey was used to evaluate the transfer status of students to determine if students were entering programs as freshmen or were transferring later in college, perhaps after completing an Associate of Art degree. In addition, the survey asked respondents about their place of residence, whether they had in-state, out-of-state, or international status.

The tranffer status between the two groups of students was found significantly different with aPhi symmetric measure value of $<0.0001$ (Table 2 ). For nonhorticulture majors, $25.2 \%$ of the respondents were transfer students. In contrast, a large percentage of students entering horticulture departments were transfer students, with $45.5 \%$ of the students entering the university after completing college courses and, in many instances, completing an AA degree. Research has indicated that $40 \%$ of college students nationwide attended community colleges(Pascarella and Terenzini, 1998). These results indicated that horticulture departments are, perhaps, attract-

T able 5. Period in which students decided to major in horticulture for students participating in the study.

\begin{tabular}{|c|c|c|c|}
\hline Q uestion & Answer & N umber & Percent \\
\hline \multicolumn{4}{|c|}{ When did you decide to major in horticulture? } \\
\hline & Earlier than high school & 1 & 0.6 \\
\hline & $\mathrm{H}$ igh school & 42 & 26.9 \\
\hline & Freshman & 32 & 20.5 \\
\hline & Sophomore & 41 & 26.3 \\
\hline & Junior & 21 & 13.5 \\
\hline & Senior & 3 & 1.9 \\
\hline & Other & 16 & 10.3 \\
\hline \multicolumn{2}{|l|}{ Total } & 156 & 100 \\
\hline
\end{tabular}




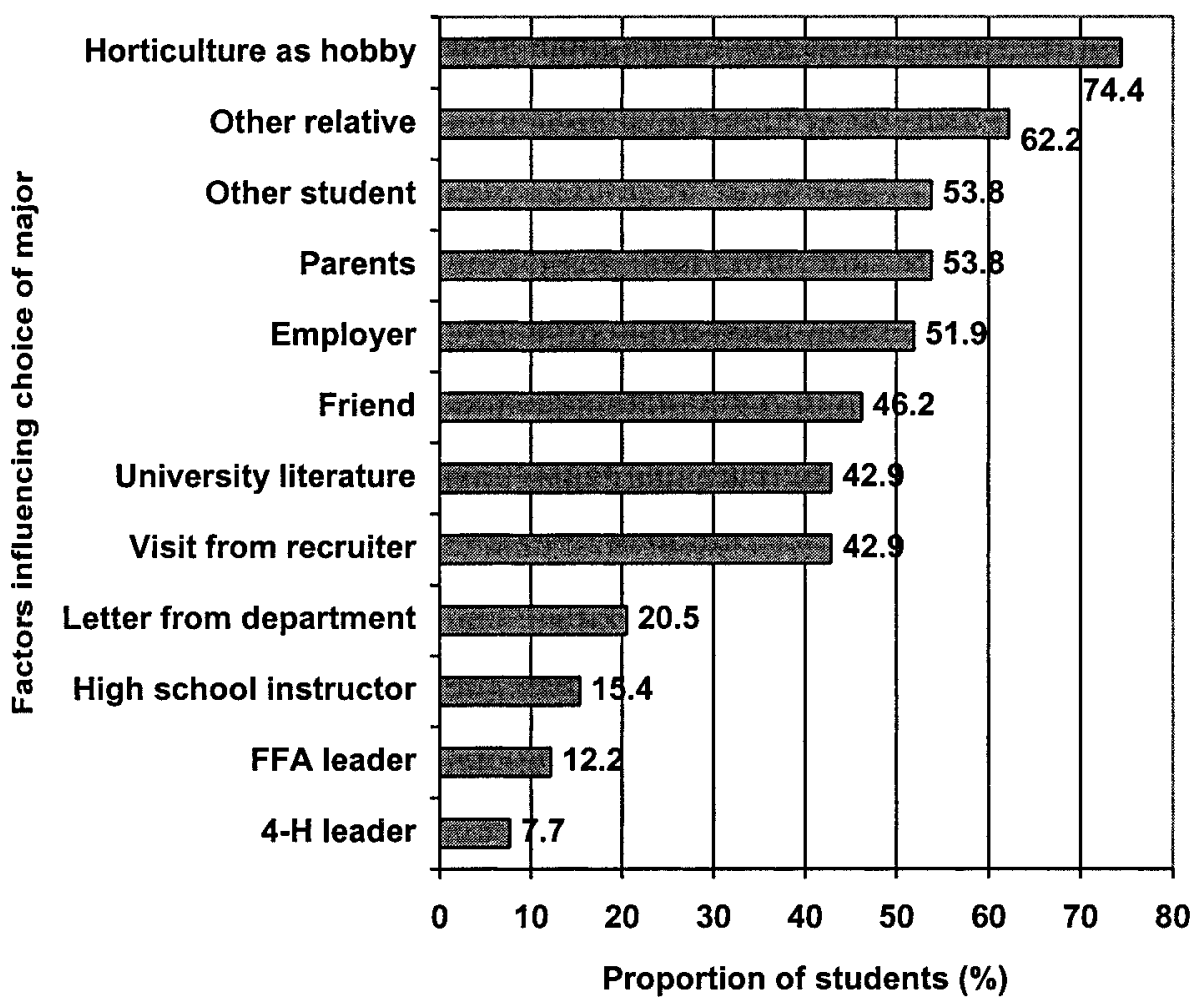

Fig. 1. Factors positively influencing horticulture as a choice of major for students participating in the study.

ing more than the national average of transfer students. This may relate to the competitiveness for students entering universities as freshmen, and their desires to pursue high-salaried professional careers.

Regarding residency, $91.2 \%$ and $85.1 \%$ of therespondentswere in-state residents, for nonhorticulture majors and horticulture majors, respectively (Table 2). Consequently, themajority of students were choosing a university that was local or within their state. This was not surprising since in-state tuition costs are generally lower and, therefore, more affordablefor students.

Objective 3: Determine if past HORTICULTURAL EXPERIENCES PLAY A ROLE IN CHOICE OF MAJ ORS FOR COLLEGE STUDENTS. A primary focus of this research was to determine what, if any, gardening experience students had before entering college and if these experiences contributed to their choice of major.

The years of gardening experience appeared to have an influence on the choice of major. This variable was found statistically significantly different with aPhi symmetric measurevalue of $<0.0001$ (T able 3 ). In total, $88 \%$ of majors had gardening experience
(Table 3), with $26.9 \%$ indicating 8 or more years of gardening experience. In contrast, $43 \%$ of the nonmajors indicated that they had never gardened versus $19 \%$ of majors. For recruiting purposes, targeting schools that already have horticulture or gardening programs might seem worthwhile. It may also beto the advantage of university horticulture programs to invest in support of community and elementary school garden programs, since these may lead, eventually, to prospective students.

Thereweresignificant differences in the perceptions of theimportance of gardening between majors and nonmajors $(\varangle 0.0001)$ (Table 4$)$. To determine the value of gardening to majors and nonmajors, students were asked to rank the importance of gardening on a Likert-type scale (Likert, 1967). Participants ranked the value of gardening from 1 to 5 , with 5 representing "very important," 4 as "important," 3 as "undecided," 2 as "unimportant," and 1 as "very unimportant." N ot surprisingly, more majors (35.3\%) ranked the value of gardening as "very important" compared to nonmajors (9.4\%) (T able 4).

Obj ective 4: Determine When MOST STUDENTS CHOOSE HORTICULTURE AS A MAJ OR AND THE PRIMARY OUTSIDE INFLUENCES THAT HELP THEM MAKE THIS DECIsıon. The survey included questionsto determine the period when students made the decision to major in horticulture, whether it wasprehigh school, high school, or college. Additionally, information was included that evaluated external influences on the decision to major in horticulture such as parents and family, high school counselors, or college literature.

Regarding the period when students made the decision to major in horticulture, the largest percentage (26.9\%) decided asearly ashigh school (Table 5). The next highest percentages decided as college freshmen or sophomores, at $20.5 \%$ and $26.3 \%$, respectively. Therefore, recruiting efforts should focus on this early period before college admittance, or perhaps, within lower level university studies. This may help capture the interest of general studiesstudentsas well asthose who are undecided.

Factors influencing selection of horticulture as a major included various external influences (Fig. 1). Of these, horticulture as a hobby had the greatest influence, with $74.4 \%$ of the respondents indicating that this interest in gardening influenced their decision to major in horticulture. In past studies, this exposure to the outdoor environment has been found to influence people's awareness of and subsequent interest in environmental career opportunities (Cooper-M arcus, 1974; Tanner, 1980).

The influence of relatives (nonparental) had a high percentage as well, with $62.2 \%$ of the respondents indicating that this group influenced their decision to major in horticulture (Figure 1). Attention should be made to the next highest percentage, which was representative of both parents and students with $53.8 \%$ For recruiting purposes, it is interesting to note that university literature as well as visits from university recruiters had a strong influence for majors, with percentages of $42.9 \%$ It is al so interesting to note that while one quarter of students have reported (in the previous section) that they made their decision to major in horticulture in high school, the lowest percentages were for high school influences. $\mathrm{H}$ igh school instructorswererated important by $15.4 \%$ of respondents. Similarly, personal influencesthat occur before college, such as the influences of aFFA leader or a $4-\mathrm{H}$ leader were rated important by only $12.2 \%$ and $7.7 \%$ of respondents, respectively. 


\section{Conclusion}

The primary purpose of thisstudy wasto determineinformation that may help universities understand their students and, ultimately, use this information towards strengthening their courses and programs through improvements in teaching and recruitment efforts. Although this study represents only a small portion of the colleges and universities teaching horticulture in theU nited States, thefindings are interesting. Results from the study indicated that there are no demographic differences between majors and nonmajors and supported research from nationwide longitudinal studies of overall collegestudent populations. However, results showed an extremely low minority representation among horticulture majors, which could, perhaps, be seen as an opportunity towards recruitment effortsin this area.

Significant differenceswerefound between horticulture majors and nonmajors on the variables of transfer status, gardening experiences, and the value of gardening. O verall, more majors had transferred into horticulture departments at universities, had more gardening experience than nonmajors, and considered the hobby of gardening as a valuable. This information should be considered in recruitment efforts since students re- ported that this interest fostered in them a desire to pursue horticulture as a major. Curriculum development, course implementation, and recruiting efforts should all relate directly to current student needsand desires. Findings from this study may prove useful in learning more about horticulture students' interests; ultimately promoting teaching and recruiting efforts better targeted to this student group.

\section{Literature cited}

Astin, A.W. 1998. Thechanging American college student: Thirty-year trends, 19661996. Rev. H igher E duc. 21(2):115-135.

Cooper-M arcus, C. 1974. The house is a symbol of self. Designing for human behavior. D ownden, H utchinson and Ross, Stroudsberg, $\mathrm{Pa}$.

H odges, A.W. 1989. O rnamental valuesin Florida. U niv. Fla. Inst. Food Agr. Sci. FRED Staff Paper. 369.

Hurtado, S., J. Milem, A. ClaytonPedersen, and W. Allen. 1998. Enhancing campus climates for racial/ ethnic diversity: E ducational policy and practice. Rev. $\mathrm{H}$ igher Educ. 21(3):279-302.

Jackson, L.R. 1998. The influence of both race and gender on the experiences of African American college women. Rev. $\mathrm{H}$ igher Educ. 21(4):359-375.

Johnson, D.C. and T.M. Johnson. 1993. Financial performance of U .S. floriculture and environmental horticulture farm businesses, 1987-91. U SD A E con. Res. Serv. Stat. Bul. 862.
Kanter, R.M . 1977. Some effects of proportions on group life: Skewed sex ratios and responses to token women. Amer. J. Sociol. 82:965-989.

Likert, R. 1967. T he method of constructing an attitude scale, p. 90-95. In: M. Fishbein (ed.). Readingsin attitude theory and measurement. Wiley, N ew York.

Pascarella, E.T. and P.T. Terenzini. 1998. Studying college students in the $21^{\text {st }}$ century: $M$ eeting new challenges. R ev. $\mathrm{H}$ igher Educ. 21(2):151-165.

Prillerman, S.L., H. M yers, and B.D. Smedley. 1989. Stress, well-being, and academic achievement in college, p. 198217. I n: G.L. Berryand J.K. A samen (eds.). Black students: Psychosocial issues and academic achievement. N ewbury Park, Calif.

Roper R eports. 1997. I nch by inch, row by row. Amer. Demogr. April. <http:/ / www.demographics.com/ publications/ ad/ 97_ad/ 9704_ad/ ad970420.htm>

Smedley, B.D ., H . M yers, and S.P. H arrell. 1993. M inority-status stresses and the college adjustment of ethnic minority freshmen. J. H igher E duc. 64(4):434-452.

Society of American Florists. 1996. The floral industry-Key facts. Soc. Amer. Florists, Alexandria, Va.

Statistical Package for the Social Sciences. 1997. SPSS 7.5 for windows. Prentice $\mathrm{H}$ all, Chicago, III.

T anner, T. 1980. Significant life experiences: A new research area in environmental education. J. Environ. E duc. 11(4):2024. 